\title{
ASSESSMENT OF SOIL PROPERTIES BY ORGANIC MATTER AND EM-MICROORGANISM INCORPORATION ${ }^{(1)}$
}

\author{
P. J . VALARINI (2), M. C. DÍAZ ALVAREZ ${ }^{(3)}$, J . M. GASCó(3), \\ F. GUERRERO(3) \& H.TOKESHI (4)
}

\begin{abstract}
SUMMARY
Properties of a claim loam soil, collected in Aranjuez (Madrid) and enriched with organic matter and microorganisms, were evaluated under controlled temperature and moisture conditions, over a period of three months. The following treatments were carried out: soil (control); soil $+50 \mathrm{t} \mathrm{ha}^{-1}$ of animal manure (E 50); soil $+50 \mathrm{tha}^{-1}$ of animal manure $+30 \mathrm{~L}^{\mathrm{h}} \mathrm{a}^{-1}$ of effective microorganisms (E 50E M); soil $+30 \mathrm{t} \mathrm{ha}^{-1}$ of the combination of various green crop residues and weeds ( $R C 30$ ) and soil $+30 \mathrm{t} \mathrm{ha}^{-1}$ of the combination of various green crop residues and weeds $+30 \mathrm{~L} \mathrm{ha}^{-1}$ of effective microorganisms (RC30E M). Soil samples were taken before and after incubation and their physical, chemical, and microbiological parameters analyzed. Significant increase was observed in the production of exopolysaccharides and basic phosphatase and esterase enzyme activities in the treatments E5OEM and RC30EM, in correlation with the humification of organic matter, water retention at field capacity, and the cationic exchange capacity (CEC) of the same treatments. The conclusion was drawn that the incorporation of a mixture of effective microorganisms (E M) intensified the biological soil activity and improved physical and chemical soil properties, contributing to a quick humification of fresh organic matter. These findings were illustrated by the microbiological activities of exopolysaccharides and by alkaline phosphatase and esterase enzymes, which can be used as early and integrated soil health indicators.
\end{abstract}

Index terms: quality indicators, microorganisms, physical, chemical, and biochemical soil properties.

(1) Parte do Treinamento de Pós-Doutoramento do primeiro autor no exterior. Recebido para publicação em maio de 2001 e aprovado em março de 2003.

(2) Pesquisador do Laboratório de Microbiologia/Fitopatologia, Embrapa Meio Ambiente/Centro Nacional de Pesquisa de Monitoramento e Avaliação do Impacto Ambiental - CNPMA. Caixa Postal 69, CEP 13820-000 J aguariúna (SP). E-mail: valarini@cnpma.embrapa.br

(3) Profesor del Departamento de Edafología de la E.T.S.I. Agrónomos - Universidad Politécnica, 28040 - Madrid - España. E-mail: fguer@eda.etsia.upm.es

(4) Professor do Departamento de Fitopatologia, Escola Superior de Agricultura "Luiz de Queiroz", Universidade de São Paulo ESALQ/USP. CEP 13418-900 Piracicaba (SP). E-mail: htokeshi@zaz.com.br 


\title{
RESUMO: AVALIAÇÃO DAS PROPRIEDADES DO SOLO APÓS A INCORPORAÇÃO DA MATÉRIA ORGÂNICA E MICROR- GANISMOS-EM
}

\begin{abstract}
As propriedades do solo foram avaliadas sob condições de temperatura e umidade control adas, após a incorporação da matéria orgânica e de microrgani smos eficazes (EM), em um solo franco argiloso coletado sob cultivos protegidos em Aranjuéz (Madrid). Os seguintes tratamentos foram empregados: solo (control e); sol o $+50 \mathrm{t} \mathrm{ha}{ }^{-1}$ deesterco deanimal (E 50); E50 +30 L ha-1 EM (E50E M); solo +30 t ha-1 derestos decultivos + plantas invasoras (RC30); RC30 + $30 \mathrm{~L} \mathrm{ha}^{-1} \mathrm{EM}$ (RC30EM). Amostras de solo foram retiradas após os tratamentos, antes eapós a incubação e anali sadas usando parâmetros físi cos, químicos e microbiológicos. Os resultados mostraram um aumento significativo na produção de exopolissacarídeos, nas atividades enzimáticas de esterases e fosfatases alcalina principalmente, nos tratamentos E50EM e RC30EM, sendo diretamente correlacionadas com a humi ficação da matéria orgânica, com a capacidadedecampo ecom a capacidadede troca catiônica desses mesmos tratamentos. A partir desses resultados, podeseconcluir que a qualidade do solo com a incorporação de EM potencializou a atividade biológica, contribuindo para uma mais rápida humificação da matéria orgâni ca fresca emel horando a estrutura e fertilidade do sol o, conforme análise das propriedades físicas e químicas, destacando-se os parâmetros microbi ológi cos como indicadores precoces de recuperação da qualidade do sol o.
\end{abstract}

Termos deindexação: indicadores dequalidade, propriedadesfísicas, químicas ebioquímicas do solo, microrganismos.

\section{INTRODUCTION}

During the last ten years, awareness has been raised about soil quality as a matter of concern throughout the world. The current concept of soil quality includes different aspects such as: soil, plant and biological productivity, environmental quality, and human and animal health (Parr et al., 1992).

Agricultural technologies and current practices like monocrops, residue management, mineral fertilization, overuse of pesticides, heavy agricultural machinery, inadequate management practices of soil and irrigation, can significantly affect the soil quality by changing their physical, chemical, and biological properties (Fauci \& Dick, 1994). In addition, the low input of organic matter into the soil in conventional production systems has caused imbalances in the edaphic ecosystems, decreasing the microbial activities of mycorrhizas, endobacteria, and plant growth promoting rhizobacteria (PGPR). This effect contributes significantly to modify plant growth by limiting plant nutrition and by making plants more susceptible to pests (García et al., 1994; Valarini et al., 1997; Frighetto et al., 1999; Agrawal et al., 1999).

Research in this respect has focused on the development of environment quality indicators and soil management practices that restore and/or improve vegetal and biological production, minimizing negative environmental impacts (Doran
\& Parkin, 1994), and contributing to theintroduction of a more sustainable agriculture (Dick, 1994). The use of animal manure, crop diversification and rotation, and the application of biological control agents are appropriate practices recommended to restore and/or improve the quality of agricultural soils. Historically and until recently, chemical and physical properties have been used as raw measures of soil productivity. However, only a static kind of data can be obtained this way. Besides, the organic matter content in soils changes very slowly over time, and therefore, many years may be required to detect changes caused by intensive agriculture or other kinds of disturbances. As far back as 1916 (Lipman et al., 1916) a lower production capacity in a soil was interpreted as the result of neglected microbiological functioning within the soil. Evidence is therefore growing that microbiological and biological soil parameters may possess potential as early and sensitive indicators for ecological soil stress or reparation (Dick, 1992; 1994; Dilly \& Blume, 1998), such as soil enzyme activities and exopolysaccharide, microbial soil biomass, composition of soil microflora, which are potential biochemical/biological indicators of soil qual ity (Dick, 1994; Fauci \& Dick, 1994; Filip, 1998). The aim of this research was to develop an efficient and fast methodol ogy that combines physical, chemical, and microbiological soil parameters to evaluate the improvement of soil quality as a function of organic matter and microorganism species incorporation in degraded soils. 


\section{MATERIAL AND METHODS}

The efficiency of incorporation of organic matter and effective microorganisms into a clay loam soil in a green house plant production in Aranjuez, Madrid - Spain was studied under laboratory conditions with controlled temperature and moisture, over a period of three months.

The experiment was conducted in a randomized block design, with five treatments and three time replicates. The following treatments were used: (a) soil (control); (b) soil + 50 t ha $^{-1}$ of animal manure (E50); (c) soil +50 t ha-1 of animal manure $+30 \mathrm{~L} \mathrm{ha}^{-1}$ of effective microorganisms (E50EM); (d) soil + $30 \mathrm{t} \mathrm{ha}^{-1}$ of fresh plant debris mixture (Zea mays L . and Brussels sprout) and weeds (Elesione indica, Cynodon dactylon, Bromus commutatus) (RC30); and e) soil $+30 \mathrm{t} \mathrm{ha}^{-1}$ of various green crop residue and weed mixture $+30 \mathrm{~L} \mathrm{ha}^{-1}$ of EM (RC30EM). The $\mathrm{C} / \mathrm{N}$ ratios of animal manureand mixed fresh plant debris and weeds (grass and vegetables) were 158 and 119, respectively. EM 4 is a probiotic of beneficial microorganisms that can be applied as soil conditioner to increase the microbial diversity. It contains selected microorganism species from beer fermentation, soybean paste and yogurt, including predominantly lactic acid bacteria (Lactobacillus plantarum and Streptococcus lactis), and smaller numbers of photosynthetic bacteria (Rhodopseudomonas capsulatus and Rhodobacter sphaeroides), actinomycets (Streptomyces albus), and yeasts (Saccharomyces cerevisiaeand Candida utilis). It is assumed that EM4 accelerates the decomposition of theremaining vegetal material, increases nutrient recycling and atmospheric nitrogen fixation, and improves soil proprieties (Tokeshi et al., 1997; Hussain et al., 1999; Sakurai, 1999). An EM4 solution was prepared and activated in the laboratory by adding glucose plus water in the

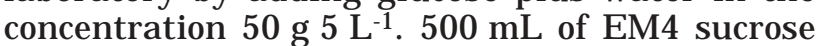
solution was left untouched for 3-4 days. In the treatments E50EM and RC30EM, the EM 4 solution was applied twice on the soil blended with organic matter: the first application was realized just after the mixing process, and the second 15 days after the initial application, in the quantities required to achieve soil field capacity as indicated by the Mokiti Okada Foundation (1993). In all other treatments, including the control, only distilled water was added to the soil, respecting the field capacity limit.

Treated soil samples were stored under laboratory conditions for one month. Afterwards, a $200 \mathrm{~g}$ sample of each treatment was incubated during one month in a $500 \mathrm{~mL}$ Erlenmeyer at $25^{\circ} \mathrm{C}$ temperature and $70 \%$ humidity of the soil field capacity, using the apparatus proposed by Guerrero (1989) to simulate the aerobic activity of the microorganisms. This system was exposed to a flow of humid and $\mathrm{CO}_{2}$-free air, which passed through
$\mathrm{NaOH}$, using phenol phthalein as indicator. The $\mathrm{CO}_{2}$ released by microorganism respiration was collected in $30 \mathrm{~mL} \mathrm{0,2} \mathrm{mol} \mathrm{L-11} \mathrm{NAOH.} \mathrm{The} \mathrm{produced} \mathrm{Na}_{2} \mathrm{CO}_{3}$ was preci pitated with $20 \% \mathrm{BaCl}_{2}$ and the excess of $\mathrm{NaOH}$ quantified with $0,2 \mathrm{~mol} \mathrm{~L}^{-1} \mathrm{HCl}$, using phenol phthal ein as indicator. The rel eased $\mathrm{CO}_{2}$ was quantified daily during four weeks.

One month after organic matter and EM4 incorporation in the soil (beforeincubation) and two months after the incubation period (three months of experiment), the soil samples were evaluated for the following physical, chemical, and biological criteria: soil texture, field capacity (\% FC), electric conductivity (EC), $\mathrm{pH}$, cationic exchange capacity (CEC), organic C, and total N (EMBRAPA, 1997). Total humic substances (THE) were extracted with a mixture of $1 \mathrm{~mol} \mathrm{~L}^{-1} \mathrm{Na}_{4} \mathrm{P}_{2} \mathrm{O}_{7}$ and $0,1 \mathrm{~mol} \mathrm{~L}^{-1}$ $\mathrm{NaOH}$, centrifuged at $3.000 \mathrm{rpm}$, and filtered using Whatman No. 42 filters (Schitzer 1982). An aliquot of this extract was acidified to $\mathrm{pH} 1$ with concentrated $\mathrm{H}_{2} \mathrm{SO}_{4}$ and centrifuged to separate humic acids $(\mathrm{HA})$. Then the HA were re-dissolved with $0,1 \mathrm{~mol} \mathrm{~L}^{-1} \mathrm{NaOH}$. The $\mathrm{C}$ contents of THE and HA were determined by the Walkcley-Blak method after being dried in a thermostatic bath at $60^{\circ} \mathrm{C}$. Values were reported on a basis of dry matter at $105^{\circ} \mathrm{C}$ ( $\mathrm{g}$ of $\mathrm{C} .100 \mathrm{~g} \mathrm{~g}^{-1}$ ). Carbon percentages in the total humic extract \% C(THE), in humic acid \% C (HA) and in fulvic acid \% C (FA) were obtained and used to calculate the indexes: \% C (THE)/\% $\mathrm{C}$ org, \% C(THE)/\% C(HA), and \% C(HA)/\% C(FA) (Nelson \& Sommer, 1982; Stevenson, 1982). Exopolysaccharide, alkaline phosphatase, and esterase enzymatic activities were determined according to Speir \& Ross (1978); Schnurer \& Rosswall (1982) and Frighetto \& Valarini (2000). Data were submitted to the mean comparative analysis (test of Tuckey, $p \leq 0.05$ ). Statistical regression analyses were performed for all the analyzed criteria in both periods (a month after the organic material was applied and at the end of the experiment).

\section{RESULTS AND DISCUSSION}

Daily mineralization curves (Figure 1 ) follow a pattern similar to the classic exponential curve of microorganism growth (Steven, 1934). Based on these curves, different phases can be observed: the first phase describes intensivemineralization during the first week of incubation, and a decrease in intensity from the seventh day; the second phase covers the reorganization and maintenance of an average mineralization activity until about the $30^{\text {th }}$ day; and the third phase is represented by an accentuated decrease in activity caused by limiting nutritional factors (Guerrero, 1989). This researcher also reported that during the growth phase, daily 
mineralization follows the derivation of the exponential curve for population growth because respiration depends on thenumber of microorganisms. However, during the decreasing phase (or third phase), the released $\mathrm{CO}_{2}$ does not directly depend on the number of microorganisms, but on other limiting factors such as nutrients. Overall C decomposition in soil was determined by the cumulative $\mathrm{CO}_{2}$ evolution. The treatments presented the same mineralization pattern, which was satisfactorily described by means of a pattern model $\left(\mathrm{CO}_{2}-\mathrm{C}=\mathrm{k} \mathrm{tm} ; \mathrm{r}=0,99 ; \mathrm{CL}=99 \%\right)$.

Table 1 shows, respectively, the physical, chemical, and microbiological parameters determined in soil samples of the different treatments, one month after mixing different types and quantities of organic matter with EM, and at the end of the experiment (three months). Results clearly show that $\mathrm{pH}$ values decreased significantly in all treatments, compared with the control (C), whereas electric conductivity (EC) increased in all treatments before incubation. After incubation, the $\mathrm{pH}$ did not differ significantly among treatments, while EC increased considerably in all treatments (Table 1). This result can be attributed to organic matter mineralization. The total organic carbon percentage $(\% \mathrm{C})$ of the control treatment, steady during the experiment, increased significantly after incubation in all mixtures, due probably to the intensive polymerization process (humification) of organic matter. The percentage of organic nitrogen
$(\% \mathrm{~N})$ increased, compared to the earlier data, although a significant increase was only noted in the E50EM treatment. Fresh or immature organic material (RC30EM) and manure (E50 and E50EM) added to soil was rapidly decomposed. According to Piccolo (1996), immature organic material with its high $\mathrm{C} / \mathrm{N}$ ratio may cause $\mathrm{N}$ immobilization with a consequent $\mathrm{N}$ deficiency in soil. Simple organicacid production may also be a cause of phytotoxicity, whereas a lower $\mathrm{C} / \mathrm{N}$ ratio may lead to $\mathrm{NH}_{3}$ evolution and plant toxicity with increased EC, possibly causing inhibition of seed germination, depression of root elongation and modification of the soil microflora. Organic amendments in the soil can influence carbon and organic nitrogen $(\mathrm{C} / \mathrm{N})$ contents significantly, benefiting microbiological and biochemical activities as indicated by the increase of exopolysaccharide, phosphatase, and esterase enzyme activities (Table 1 ). Generally, the $\mathrm{C} / \mathrm{N}$ ratio is used as an indicator for theevolution of theorganic matter decomposition process. According to Burés (1997), C/N ratios in the soil ranging from 15 to 30 are suitablevalues, while according to Kiehl (2001), ratios are constant and adequate from 10 to 12, as obtained in this assay with the treatments RC30EM, E50 and E50EM, favorable for microorganism growth and protein synthetization. Results were confirmed by alterations of the humificated fraction (\% CHA and \% CFA), although in \% CTHE there is a clear influence of both the remaining crop material and manure. This result can be explained mainly

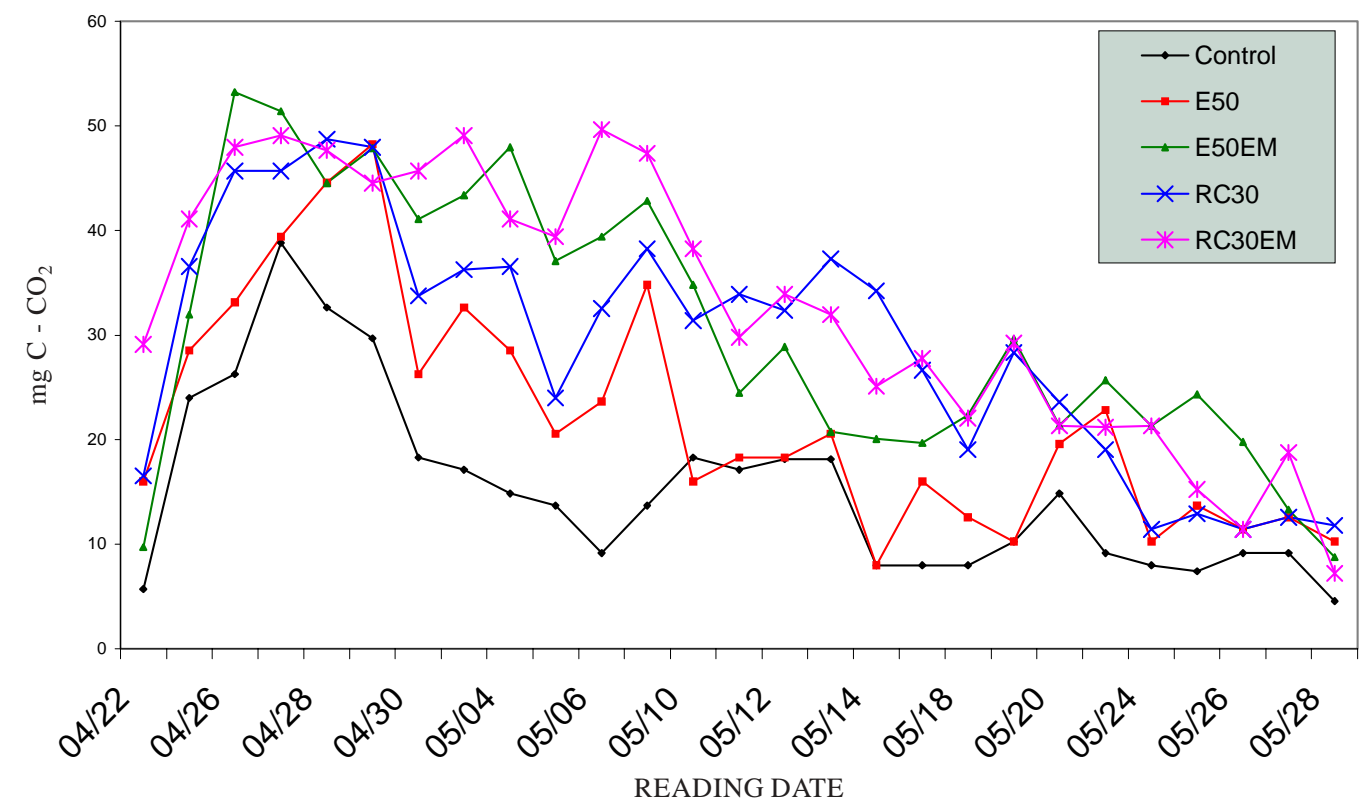

Control $=$ soil; $\mathrm{E} 50=$ soil $+50 \mathrm{t} \mathrm{ha}^{-1}$ of animal manure; $\mathrm{E} 50 \mathrm{EM}=$ soil $+50 \mathrm{t} \mathrm{ha}^{-1}$ of animal manure $+30 \mathrm{~L} \mathrm{ha}^{-1}$ of effective microorganisms (EM); RC30 = soil $+30 \mathrm{t} \mathrm{ha}^{-1}$ of mixed fresh plant debris; $E M(R C 30 E M)=s o i l+30 \mathrm{t} \mathrm{ha}^{-1}$ of mixed of various green crop residues and weeds $+30 \mathrm{~L} \mathrm{ha}^{-1}$ of EM.

Figure 1. Determination of total microbial activity $\left(\mathrm{mg} \mathrm{CO}_{2}-\mathrm{C}\right)$ in samples of a claim loam soil mixed with different kinds of organic matter and incubated at $25^{\circ} \mathrm{C}$. 
by the \% CTHE/\% C and \% CHA/\% CFA indexes, where higher values corresponded to a higher humification rate and a higher degree of the humifyed polymeralization fraction, distinct in the treatments E50 and E50EM. Humic substances with abiotic characteristics represented the most important portion of the soil organic matter, from both the quantitative and qualitative point of view. Furthermore, the change in quantity and quality of soil organic matter, i.e., humic substances and the ratio Humic Acids/Fulvic Acids, can be indicative of agradative, and, or degradative processes in a soil ecosystem. Content and quality of humus-like substances in the end-product are considered important indicators for maturity and stability of the organic matter, essential for a successful application in agriculture and a reduced environmental impact of the amendment (Piccolo, 1996; Filip, 1998).

Similar results were observed for the water retention capacity (\% FC), especially where manure and remaining organic crop material was added (E50, E50EM and RC30EM). All mixtures enhanced $\%$ FC significantly compared with the control (C). The cationic exchange capacity (CEC) was only influenced significantly in the treatment manure plus mi croorganisms (E 50EM) before incubation and in the treatments E50 and E50EM after incubation. Alkalinephosphatases, esterases, and exopolysaccharides

Table 1. Physical, chemical and microbiological parameters of a claim loam soil with kinds and amounts of organic matter incorporated, before and after incubation

\begin{tabular}{|c|c|c|c|c|c|}
\hline \multirow{2}{*}{ Parameter } & \multicolumn{5}{|c|}{ Treatment(1) } \\
\hline & C & RC30 & RC30E M & E50 & E50EM \\
\hline $\begin{array}{l}\mathrm{pH}^{(2)} \\
\mathrm{pH}^{(3)}\end{array}$ & $\begin{array}{l}7.79 \mathrm{a} \\
7.74 \mathrm{a}\end{array}$ & $\begin{array}{l}7.36 \mathrm{~b} \\
7.74 \mathrm{a}\end{array}$ & $\begin{array}{l}7.43 \mathrm{~b} \\
7.26 \mathrm{a}\end{array}$ & $\begin{array}{l}7.42 \mathrm{~b} \\
7.65 \mathrm{a}\end{array}$ & $\begin{array}{l}7.39 \mathrm{~b} \\
7.40 \mathrm{a}\end{array}$ \\
\hline $\begin{array}{l}\text { EC }\left(\mu S \mathrm{~cm}^{-1} \text { a } 25^{\circ} \mathrm{C}\right)^{(2)} \\
\text { EC }\left(\mu \mathrm{S} \mathrm{cm} \mathrm{cm}^{-1} \text { a } 25^{\circ} \mathrm{C}\right)^{(3)}\end{array}$ & $\begin{array}{l}624 a \\
896 a\end{array}$ & $\begin{array}{l}864 a b \\
1283 a\end{array}$ & $\begin{array}{l}1529 c \\
1429 a b\end{array}$ & $\begin{array}{l}1200 \mathrm{bc} \\
3077 \mathrm{c}\end{array}$ & $\begin{array}{l}1476 \mathrm{c} \\
2339 \mathrm{bc}\end{array}$ \\
\hline $\begin{array}{l}\% C\left(\mathrm{~g} \mathrm{~kg}^{-1}\right)^{(2)} \\
\% \mathrm{C}\left(\mathrm{g} \mathrm{kg}^{-1}\right)^{(3)}\end{array}$ & $\begin{array}{l}1.49 \mathrm{a} \\
1.49 \mathrm{a}\end{array}$ & $\begin{array}{l}1.69 \mathrm{a} \\
2.71 \mathrm{~b}\end{array}$ & $\begin{array}{l}1.72 \mathrm{a} \\
3.76 \mathrm{c}\end{array}$ & $\begin{array}{l}1.54 \mathrm{a} \\
3.67 \mathrm{c}\end{array}$ & $\begin{array}{l}2.04 \mathrm{~b} \\
4.32 \mathrm{~d}\end{array}$ \\
\hline $\begin{array}{l}\% \mathrm{~N}\left(\mathrm{~g} \mathrm{~kg}^{-1}\right)^{(2)} \\
\% \mathrm{~N}\left(\mathrm{~g} \mathrm{~kg}^{-1}\right)^{(3)}\end{array}$ & $\begin{array}{l}0.15 a \\
0.20 a\end{array}$ & $\begin{array}{l}0.21 \mathrm{a} \\
0.24 \mathrm{a}\end{array}$ & $\begin{array}{l}0.21 a \\
0.29 a\end{array}$ & $\begin{array}{r}0.3 \mathrm{~b} \\
0.30 \mathrm{a}\end{array}$ & $\begin{array}{l}0.33 \mathrm{~b} \\
0.33 \mathrm{~b}\end{array}$ \\
\hline $\begin{array}{l}\mathrm{C} / \mathrm{N}^{(2)} \\
\mathrm{C} / \mathrm{N}^{(3)}\end{array}$ & $\begin{array}{l}9.93 a \\
7.45 a\end{array}$ & $\begin{array}{r}8.05 a \\
10.29 a\end{array}$ & $\begin{array}{r}8.19 a \\
12.96 \mathrm{~b}\end{array}$ & $\begin{array}{r}5.13 \mathrm{~b} \\
12.53 \mathrm{~b}\end{array}$ & $\begin{array}{r}6.18 \mathrm{~b} \\
12.34 \mathrm{~b}\end{array}$ \\
\hline $\begin{array}{l}\% \mathrm{FC}^{(2)} \\
\% \mathrm{FC}^{(3)}\end{array}$ & $\begin{array}{l}22.98 a \\
24.57 a\end{array}$ & $\begin{array}{l}25.03 \mathrm{~b} \\
25.71 \mathrm{a}\end{array}$ & $\begin{array}{l}29.59 \mathrm{c} \\
34.21 \mathrm{c}\end{array}$ & $\begin{array}{l}30.56 \mathrm{~cd} \\
31.28 \mathrm{~b}\end{array}$ & $\begin{array}{l}31.33 d \\
34.37 c\end{array}$ \\
\hline $\begin{array}{l}\operatorname{CEC}\left(\mathrm{mmol} \mathrm{dm}^{-3}\right)^{(2)} \\
\operatorname{CEC}\left(\mathrm{mmol} \mathrm{dm}^{-3}\right)^{(3)}\end{array}$ & $\begin{array}{l}13.74 \mathrm{a} \\
14.61 \mathrm{a}\end{array}$ & $\begin{array}{l}14.6 \mathrm{a} \\
14.6 \mathrm{a}\end{array}$ & $\begin{array}{l}14.43 a \\
15.01 \mathrm{ab}\end{array}$ & $\begin{array}{l}15.65 a \\
16.42 b c\end{array}$ & $\begin{array}{l}16.43 \mathrm{~b} \\
16.85 \mathrm{c}\end{array}$ \\
\hline $\begin{array}{l}\% \mathrm{CTHE}^{(2)} \\
\% \mathrm{CTHE}^{(3)}\end{array}$ & $\begin{array}{l}0.53 a \\
0.98 a\end{array}$ & $\begin{array}{l}1.03 \mathrm{~b} \\
1.36 \mathrm{~b}\end{array}$ & $\begin{array}{l}1.13 b \\
2.14 c\end{array}$ & $\begin{array}{l}1.02 \mathrm{~b} \\
1.91 \mathrm{c}\end{array}$ & $\begin{array}{l}1.36 \mathrm{c} \\
2.42 \mathrm{c}\end{array}$ \\
\hline $\begin{array}{l}\% \mathrm{CHA}^{(2)} \\
\% \mathrm{CHA}\end{array}$ & $\begin{array}{l}0.21 \mathrm{a} \\
0.47 \mathrm{a}\end{array}$ & $\begin{array}{l}0.22 \mathrm{a} \\
0.47 \mathrm{a}\end{array}$ & $\begin{array}{l}0.40 \mathrm{~b} \\
0.90 \mathrm{~b}\end{array}$ & $\begin{array}{l}0.60 \mathrm{c} \\
1.14 \mathrm{c}\end{array}$ & $\begin{array}{l}0.76 \mathrm{~d} \\
1.43 \mathrm{~d}\end{array}$ \\
\hline $\begin{array}{l}\% \mathrm{CFA}^{(2)} \\
\% \mathrm{CFA}^{(3)}\end{array}$ & $\begin{array}{l}0.32 \mathrm{a} \\
0.51 \mathrm{a}\end{array}$ & $\begin{array}{l}0.72 b \\
0.88 a b c\end{array}$ & $\begin{array}{l}0.74 \mathrm{~b} \\
1.15 \mathrm{c}\end{array}$ & $\begin{array}{l}0.39 c \\
0.80 a b\end{array}$ & $\begin{array}{l}0.58 \mathrm{c} \\
0.99 \mathrm{ac}\end{array}$ \\
\hline $\begin{array}{l}\% \mathrm{CTHE} / \% \mathrm{CHA}^{(2)} \\
\% \mathrm{CTHE} / \% \mathrm{CHA}^{(3)}\end{array}$ & $\begin{array}{l}2.52 \mathrm{ab} \\
2.07 \mathrm{a}\end{array}$ & $\begin{array}{l}4.16 \mathrm{c} \\
2.87 \mathrm{~b}\end{array}$ & $\begin{array}{l}2.93 \mathrm{~b} \\
2.24 \mathrm{a}\end{array}$ & $\begin{array}{l}1.64 \mathrm{a} \\
1.64 \mathrm{a}\end{array}$ & $\begin{array}{l}1.75 a \\
1.69 a\end{array}$ \\
\hline $\begin{array}{l}\% \text { CTHE/\%C(2) } \\
\% \text { CTHE } \% \mathrm{C}^{(3)}\end{array}$ & $\begin{array}{l}0.35 \mathrm{a} \\
0.66 \mathrm{~b}\end{array}$ & $\begin{array}{l}0.64 \mathrm{~b} \\
0.52 \mathrm{a}\end{array}$ & $\begin{array}{l}0.68 \mathrm{~b} \\
0.57 \mathrm{a}\end{array}$ & $\begin{array}{l}0.69 \mathrm{~b} \\
0.51 \mathrm{a}\end{array}$ & $\begin{array}{l}0.66 \mathrm{~b} \\
0.58 \mathrm{a}\end{array}$ \\
\hline $\begin{array}{l}\% \mathrm{CHA} / \% \mathrm{CFA}^{(2)} \\
\% \mathrm{CHA} / \% \mathrm{CFA}(3)\end{array}$ & $\begin{array}{l}0.67 \mathrm{a} \\
0.93 \mathrm{ab}\end{array}$ & $\begin{array}{l}0.32 \mathrm{a} \\
0.54 \mathrm{a}\end{array}$ & $\begin{array}{l}0.52 \mathrm{a} \\
0.81 \mathrm{a}\end{array}$ & $\begin{array}{l}1.56 \mathrm{~b} \\
1.56 \mathrm{~b}\end{array}$ & $\begin{array}{l}1.33 \mathrm{~b} \\
1.45 \mathrm{~b}\end{array}$ \\
\hline $\begin{array}{l}\text { Alkaline Phosphatase }\left(\mu \mathrm{g} \mathrm{g}^{-1} \mathrm{~h}^{-1} \text { soil)(2) }\right. \\
\text { Alkaline Phosphatase }\left(\mu \mathrm{g} \mathrm{g}^{-1} \mathrm{~h}^{-1} \text { soil }\right)^{(3)}\end{array}$ & $\begin{array}{r}66.54 \mathrm{a} \\
152.14 \mathrm{a}\end{array}$ & $\begin{array}{l}125.76 \mathrm{~b} \\
344.65 \mathrm{bc}\end{array}$ & $\begin{array}{l}163.40 \mathrm{c} \\
394.11 \mathrm{c}\end{array}$ & $\begin{array}{l}114.98 \mathrm{~b} \\
320.09 \mathrm{~b}\end{array}$ & $\begin{array}{l}127.08 \mathrm{~b} \\
564.17 \mathrm{~d}\end{array}$ \\
\hline $\begin{array}{l}\text { Esterases }\left(\mu \mathrm{g} \mathrm{g}^{-1} \mathrm{~h}^{-1} \text { soil }\right)^{(2)} \\
\text { Esterases }\left(\mu \mathrm{g} \mathrm{g}^{-1} \mathrm{~h}^{-1} \text { soil }\right)^{(3)}\end{array}$ & $\begin{array}{l}35.10 a \\
40.39 a\end{array}$ & $\begin{array}{l}60.24 c \\
49.81 a b\end{array}$ & $\begin{array}{l}81.45 c \\
92.37 c\end{array}$ & $\begin{array}{l}47.97 \mathrm{~b} \\
59.60 \mathrm{ab}\end{array}$ & $\begin{array}{l}69.37 \mathrm{~d} \\
75.10 \mathrm{bc}\end{array}$ \\
\hline $\begin{array}{l}\text { Exopol ysaccharides }\left(\mathrm{mg} \mathrm{g}^{-1} \text { soil }\right)^{(2)} \\
\text { Exopolysaccharides }\left(\mathrm{mg} \mathrm{g}^{-1} \text { soil }\right)^{(3)}\end{array}$ & $\begin{array}{l}0.04 a \\
0.26 a\end{array}$ & $\begin{array}{l}0.06 \mathrm{~b} \\
0.71 \mathrm{~b}\end{array}$ & $\begin{array}{l}0.08 \mathrm{~b} \\
0.96 \mathrm{~cd}\end{array}$ & $\begin{array}{l}0.12 c \\
0.89 b c\end{array}$ & $\begin{array}{l}0.13 \mathrm{c} \\
1.11 \mathrm{~d}\end{array}$ \\
\hline
\end{tabular}

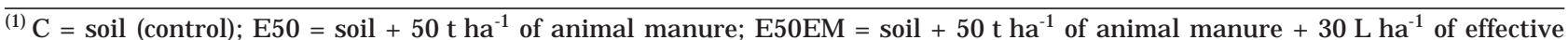
microorganisms (EM); RC30 = soil $+30 \mathrm{t} \mathrm{ha}^{-1}$ of mixed fresh plant debris; $\mathrm{EM}(\mathrm{RC} 30 \mathrm{EM})=$ soil $+30 \mathrm{t} \mathrm{ha}^{-1}$ of mixed of various green crop residues and weeds $+30 \mathrm{~L} \mathrm{ha}^{-1}$ of EM. ${ }^{(2)}$ one and ${ }^{(3)}$ months after addition of organic matter in the soil. Average of three replications. Values in horizontal row followed by the same letter(s) are not significantly different according to Tuckey ( $\leq 0.05)$. 
also revealed this significant trend, mainly in the treatments RC30EM and E50EM after incubation (Table 1). Sarmentero et al. (1994) reported that the activity of certain enzymes such as dehydrogenase is used to quantify the total microbial activity of a soil with a good correlation of this activity to other processes such as soil respiration. However, the hydrolysis of fluoresceina diacetate was more sensitiveand rapid than the dehydrogenaseactivity, demonstrating that esterase quantification represents an efficient indicator of microbial activity in soils. The significance of carbohydrates in soil arises largely from the ability of complex polysaccharides to bind inorganic soil particles into stableaggregates. Also, according to Robert \& Chenu (1992), polysaccharides form complexes with metal ions in the soil and build blocks for humus synthesis. Besides the effects on physical soil properties, other soil characteristics affected by exopolysaccharides include since chemical (CEC, anion retention) until additional effect of $\mathrm{N}$ and $\mathrm{P}$ for plant growth and biological activity as, e.g., energy source for microorganisms ( Stevenson, 1982; Frighetto \& Valarini, 2000).

Significant correlations were observed between exopolysaccharide and alkaline phosphatase $(0.92 * *)$, exopolysaccharideand esterase $(0.79 *)$, and exopolysaccharide and CEC $\left(0.71^{*}\right)$, indicating that some microbiological, physical, and chemical parameters are complementary. However, results showed that microbiological parameters are sensitive indicators of changes and improvements in structure and soil fertility in a very short time. This result confirms that this investigation should be accompanied by the simultaneous determination of basic physical and chemical soil characteristics such as pH, CEC, EC, and FC. These abiotic characteristics are complementary for a better understanding of the biological and biochemical properties and support the final evaluation of soil quality (Mäder et al., 1997; Filip, 1998; Kumar \& Goh, 2000). It is unlikely that a single absolute soil enzymeactivity or any other biological measurement could bereliably used to assess soil quality, because soils naturally vary widely in biological activity; also, soil enzyme activities have not consistently correlated to crop productivity. However, these parameters may only be used as components of an universal composed index that aggregates several biological, chemical, and physical key parameters for determining soil quality in relation to plant growth (Dick, 1994; Doran \& Parkin, 1994; F auci \& Dick, 1994; Dilly \& Blume, 1998).

Regarding the probiotic treatments, EM works as an activator of soil microorganism populations and an ameliorator of physical and chemical soil properties (Tokeshi et al., 1997; Frighetto et al., 1999; Hussain et al., 1999). Thus, it can beconcluded that EM potentialized the biological soil activity, contributing to a quick humification of fresh or immature organic matter. As found in this work, the process can be monitored with microbiological and biochemical indicators such as exopolysaccharide and alkaline phosphatase and esterase enzymes. It is also clear that these indicators are closely related to certain physical and chemical characteristics, such as the cationic exchange capacity (CEC) and, to a lesser extent, to field capacity (FC). These results agree with those obtained by other authors (Mäder et al., 1997; Tokeshi et al., 1997; Frighetto et al., 1999; Valarini et al., 1999).

\section{CONCLUSIONS}

1. I ncorporation of efficient mi croorganisms (EM) potentialized thebiol ogical soil activity, contributing to a quick humification of fresh organic matter.

2. Exopolysaccharide, alkal ine phosphatase and esterase activities may be used as early indicators of soil health.

\section{ACKNOWLEDGME NT}

To Dr. Clayton Campanhola and Dra Maria J osé Valarini, for their careful English reviews of this manuscript.

\section{LITERATURE CITED}

AGRAWAL, A.A.; TUZUN, S. \& BENT, E. Induced plant defenses against pathogens and herbivores: biochemistry, ecology and agriculture. St. Paul, APS Press, 1999. 390p.

BURÉS, S. Sustratos. Madrid, Ediciones Agrotécnicas J .L., 1997. $342 \mathrm{p}$.

DICK, R.P. A review: long-term effects of agricultural systems on soil biochemical and microbial parameters. Agric. Ecosyst. Environ., 40:25-60, 1992.

DICK, R.P. Soil enzyme activities as indicators of soil quality. In: DORAN, J.W.; COLEMAN, D.C.; BEZDICEK, D.F. \& STEWART, B.A., eds. Defining soil quality for a sustainable environment. Minneapolis, Soil Science Society of America, 1994. p.107-124. (SSSA Special Publication, 35)

DILLY, O. \& BLUME, H.P. Indicators to assess sustainable land use with reference to soil microbiology. Adv. GeoE col., 31:29-36, 1998.

DORAN, J.W. \& PARKIN, J.B. Defining and assessing soil quality. In: DORAN, J.W.; COLEMAN, D.C.; BEZDICEK, D.F. \& STEWART, B.A., eds. Defining soil quality for a sustainable environment. Minneapolis, Soil Science Society of America, 1994. cap.1, p.3-22. (SSSA Special Publication, 35)

EMPRESA BRASILEIRA DE PESQUISA AGROPECUÁRIA EMBRAPA. Serviço Nacional de Levantamento e Conservação de Solos. Manual de métodos de análise de solo. 2.ed. Rio de J aneiro, EMBRAPA-CNPS, 1997. 212p. (EMBRAPA-CNPS. Documentos, 1) 
FAUCI, M.F. \& DICK, R.P. Microbial biomass as an indicator of soil quality: effects of long-term management and recent soil amendments. In: DORAN, J.W.; COLEMAN, D.C.; BEZDICEK, D.F. \& STEWART, B.A., eds. Defining soil quality for a sustainable environment. Minneapolis, Soil Science Society of America, 1994. 17:229-234. (SSSA Special Publication, 35)

FILIP, Z.K. Soil quality assessment: an ecological attempt using microbiological and biochemical procedures. Adv. GeoE col., 31:21-27, 1998.

FRIGHETTO, R.T.S.; VALARINI, P.J .; TOKESHI, H. \& OLIVEIRA, D.A. Action of effective microorganisms EM on microbial, biochemical and compaction parameters of sustainable soil in Brazil. In: INTERNATIONAL CONFERENCE ON KYUSEI NATURE FARMING, 5., Bangkok, 1997. Proceedings. Bangkok, Asia Pacific Natural Agriculture Network, 1999. p.159-164.

FRIGHETTO, R.T.S. \& VALARINI, P.J . Indicadores biológicos e bioquímicos da qualidade do solo: manual técnico. J aguariúna, Embrapa Meio Ambiente, 2000. 198p. (E mbrapa Meio Ambiente. Documentos, 21)

FUNDAÇÃO MOKITI OKADA - FMO. Experimentos sobre o uso dos microrganismos eficazes (EM) no Brasil. In: INTERNATIONAL CONFERENCE ON KYUSEI NATURE FARMING, 3., Santa Barbara. Proceedings., IFOAM, 1993. p.190-192.

GARCÍA, C.; HERNANDEZ, T.; COSTA, F. \& CECCANTI, B. Biochemical parameters in soils regenerated by the addition of organic wastes. Waste Managem. Res., 12:457-466, 1994.

GUERRERO, F. Estudio de las propiedades físicas y químicas de al gunas turbas españolas y su posible aprovechamiento agricola. Madrid, Universidad Autonoma de Madrid, 1989. 234p. (Tese de Doutorado)

HUSSAIN, T.; J AVAID, T.; PARR, J .F.; J ILANOI, G. \& HAQ, $M . A$. Rice and wheat production in Pakistan with effective microorganisms. Am. J . Altern. Agric., 14:30-36, 1999.

KIEHL, J .C. Produção de composto orgânico e vermicomposto. Inf. Agropec., 22:40-42 e 47-52, 2001.

KUMAR, K. \& GOH, K.M. Crop residues and management practices: effects on soil quality, soil nitrogen dynamics, crop yield and nitrogen recovery. Adv. Agron., 68:97-279, 2000.

LIPMAN, J .G.; MCLEAN, H. \& LINT, H.C. Sulphur oxidation in soils and its effect on the availability of mineral phosphatases. Soil Sci., 1:533-539, 1916.

MÄDER,P.; PFIFFNER, L.; FLIESSBACH, A.; VON-LÜTZOW, M. \& MUNCH, J.C. Soil ecology- Impact of organic and conventional agriculture on soil biota and its significance for soil fertility. In: INTERNATIONAL CONFERENCE ON KYUSEI NATURE FARMING, 5., Bangkok, 1997. Proceedings. Bangkok, Asia Pacific Natural Agriculture Network, 1997. p.24-40.

NELSON D.W. \& SOMMERS, L.E. Total carbon, organic carbon and organic matter. In: PAGE A.L.; MILLERR. H.; KEENEY, D.R., eds. Methods of soil analysis, part. 2 . Chemical and microbiological properties, $2^{\text {nd }}$ edn. (Agronomy series no. 99 ASSA, SSSA, Madison, Wis., p:539579, 1982.
PARR, J .F .; PAPENDICK, R.I .; HORNICK, S.B. \& MEYER, R.E. Soil quality: attributes and relationship to alternative and sustainableagriculture. Am. J . Altern. Agric., 7:5-11, 1992.

PICCOLO, A. Humus and soil conservation. In: PICCOLO, A., ed. Humic substances in terrestrial ecosystems. Amsterdam, Elsevier Applied Science, 1996. p.225-264.

ROBERT, M. \& CHENU, C. Interactions between soil minerals and microorganisms. In: STOTZKY, G. \& BOLLAG, J -M., ed. Soil Biochemistry. New York: Marcel Deckker, 7:307404, 1992.

SAKURAI, M. Co-existence of photosynthetic bacterias streptomyces and lactic acid bacteria in solutions of effective microorganisms. In: INTERNATIONAL CONFERENCE ON KYUSEI NATURE FARMING, 5., Bangkok, 1997. Proceedings. Bangkok, Asia Pacific Natural Agriculture Network, 1999. p.379-385.

SARMENTERO, J.P.; MOLINA, A. \& COLMENARES, R. Influencia del abonado com compost y fertilizantes solubles sobre la actividad enzimática del suelo y la calidad del cultivo avena-veza en una finca de la alta montaña madrileña. In: CONGRESO DE LA SOCIEDAD ESPAÑOLA DE AGRICULTURA ECOLÓGICA, Toledo, 1994. Anales. Toledo, Sociedad Española de Agricultura Ecológica, 1994. p.47-56.

SCHITZER, M. Extraction, fractionation and characterzation of soil organic matter.In: PAGE A.L., MILLERR.H.; KEENEY D.R., eds. Methods of soil analysis, part.2. Chemical and microbiological properties, 2.ed. SSSA, Madison, 1982. p.539-579. (Agronomy series no. 99)

SCHNURER, J \& \& ROSSWALL, T. Fluorescent diacetate hydrolysis as a measure of total microbial activity in soil and litter. Appl. Environ. Microbiol., 6:1256-1261, 1982.

SPEIR, T.W. \& ROSS, D.J. Soil phosphatase and sulphatase. In: BURNS, R.G., ed. Soil enzymes. New York, Academic Press, 1978. p.197-250

STEVEN, A. Studies on tropical soil microbiology: I. The evolution of carbon dioxide from the soil and bacterial growth curve. Soil Sci., 37:109-115, 1934.

STEVENSON, F.J. Humus chemistry: genesis, composition, reaction. New York, J ohn Wiley \& Sons, 1982, 443p.

TOKESHI, H.; ALVES, M.C.; SANCHES, A.B. \& HARADA, D.Y. Control of Sclerotinia sclerotiorum with effective microorganisms. Summa Phytopathol., 23:146-154, 1997.

VALARINI, P.J .; FRIGHETTO, R.T.A.; TOKESHI, H. \& OLIVEIRA, D.A. Action of effective microorganisms (EM) in soil of intensive agricultural system in Brazil. In: INTERNATIONAL CONFERENCE ON KYUSEI NATURE FARMING, 5., Bangkok, 1997. Proceedings angkok, Asia Pacific Natural Agriculture Network, 1997. p.15-16.

VALARINI, P.J .; FRIGHETTO, R.T.S.; TOKESHI, H.; SCRAMIN, S.; SILVEIRA, A.P.D.; VALARINI, M.J \& \& OLIVEIRA, D.A. Physico-chemical and microbiological properties of soil as affected by irrigated agricultural systems. In: FOGUELMAN, D.; LOCKERETZ, W., ed. Organic agriculture the credible solution for the $\left.X X\right|^{\text {st }}$ Century. INTERNATIONAL IFOAM SCIENTIFIC CONFERENCE, 12., Mar del Plata, 1999. Proceedings. IFOAM, 1999. p.165-171. 